Old Dominion University

ODU Digital Commons

4-2018

\title{
Assessing Phytoplankton Nutritional Status and Potential Impact of Wet Deposition in Seasonally Oligotrophic Waters of the Mid- Atlantic Bight
}

\author{
P. N. Sedwick \\ Old Dominion University, Psedwick@odu.edu \\ P. W. Bernhardt \\ Old Dominion University \\ M. R. Mulholland \\ Old Dominion University, mmulholl@odu.edu \\ R. G. Najjar \\ L. M. Blumen \\ Old Dominion University
}

See next page for additional authors

Follow this and additional works at: https://digitalcommons.odu.edu/oeas_fac_pubs

Part of the Biogeochemistry Commons, Marine Biology Commons, and the Oceanography Commons

\section{Original Publication Citation}

Sedwick, P. N., Bernhardt, P. W., Mulholland, M. R., Najjar, R. G., Blumen, L. M., Sohst, B. M., . . Widner, B. (2018). Assessing phytoplankton nutritional status and potential impact of wet deposition in seasonally oligotrophic waters of the Mid-Atlantic Bight. Geophysical Research Letters, 45(7), 3203-3211. doi:10.1002/2017gl075361

This Article is brought to you for free and open access by the Ocean \& Earth Sciences at ODU Digital Commons. It has been accepted for inclusion in OES Faculty Publications by an authorized administrator of ODU Digital Commons. For more information, please contact digitalcommons@odu.edu. 


\section{Authors}

P. N. Sedwick, P. W. Bernhardt, M. R. Mulholland, R. G. Najjar, L. M. Blumen, B. M. Sohst, C. Sookhdeo, and Brittany Widner 


\section{Geophysical Research Letters}

\section{RESEARCH LETTER}

10.1002/2017GL075361

Key Points:

- Nitrogen is the proximate limiting nutrient for phytoplankton growth in seasonally oligotrophic waters of the southern Mid-Atlantic Bight during summer

- Phosphorus availability exerts a secondary limitation on phytoplankton growth during summer, which may limit the impact of wet deposition on primary production

- Contrary to previous findings, our results provide no evidence that availability of dissolved iron limits phytoplankton growth in this ocean region during summer

Supporting Information:

- Supporting Information S1

- Table S1

Correspondence to:

P. N. Sedwick,

psedwick@odu.edu

Citation:

Sedwick, P. N., Bernhardt, P. W., Mulholland, M. R., Najjar, R. G., Blumen, L. M., Sohst, B. M., et al. (2018). Assessing phytoplankton nutritional status and potential impact of wet deposition in seasonally oligotrophic waters of the Mid-Atlantic Bight. Geophysical Research Letters, 45, 3203-3211. https://doi.org/10.1002/ 2017GL075361

Received 17 AUG 2017 Accepted 9 MAR 2018 Accepted article online 12 MAR 2018 Published online 6 APR 2018

C2018. American Geophysical Union. All Rights Reserved.

\section{Assessing Phytoplankton Nutritional Status and Potential Impact of Wet Deposition in Seasonally Oligotrophic Waters of the Mid-Atlantic Bight}

\author{
P. N. Sedwick' ${ }^{1}$, P. W. Bernhardt' ${ }^{1}$ D, M. R. Mulholland ${ }^{1}$, R. G. Najjar ${ }^{2}$ (D) L. M. Blumen ${ }^{1}$, \\ B. M. Sohst ${ }^{1}$ iD, C. Sookhdeo ${ }^{1}$, and B. Widner ${ }^{3}$ iD \\ ${ }^{1}$ Department of Ocean, Earth and Atmospheric Sciences, Old Dominion University, Norfolk, VA, USA, ${ }^{2}$ Department of \\ Meteorology and Atmospheric Science, The Pennsylvania State University, University Park, PA, USA, ${ }^{3}$ Department of Marine \\ Chemistry and Geochemistry, Woods Hole Oceanographic Institution, Woods Hole, MA, USA
}

Abstract To assess phytoplankton nutritional status in seasonally oligotrophic waters of the southern Mid-Atlantic Bight, and the potential for rain to stimulate primary production in this region during summer, shipboard bioassay experiments were performed using natural seawater and phytoplankton collected north and south of the Gulf Stream. Bioassay treatments comprised iron, nitrate, iron + nitrate, iron + nitrate + phosphate, and rainwater. Phytoplankton growth was inferred from changes in chlorophyll $a$, inorganic nitrogen, and carbon-13 uptake, relative to unamended control treatments. Results indicated the greatest growth stimulation by iron + nitrate + phosphate, intermediate growth stimulation by rainwater, modest growth stimulation by nitrate and iron + nitrate, and no growth stimulation by iron. Based on these data and analysis of seawater and atmospheric samples, nitrogen was the proximate limiting nutrient, with a secondary limitation imposed by phosphorus. Our results imply that summer rain events increase new production in these waters by contributing nitrogen and phosphorus, with the availability of the latter setting the upper limit on rain-stimulated new production.

Plain Language Summary Human activities have substantially increased the atmospheric loading and deposition of biologically available nitrogen, an essential nutrient, to the surface ocean. Such atmospheric inputs to the ocean will likely impact on oceanic primary production by phytoplankton, and thus the marine ecosystem and ocean carbon cycling, although the scale and spatial distribution of such impacts are not well known. In this study, we used shipboard experiments, observations, and laboratory measurements to assess the potential impacts of atmospheric nitrogen deposition in rainfall on oceanic waters of the Mid-Atlantic Bight, off the U.S. eastern seaboard, during the summer. We find that the growth of phytoplankton in these waters is limited by the availability of nitrogen during summer, such that nitrogen added to the ocean by summer rain events can considerably stimulate phytoplankton primary production. However, the biological impact of these rainwater nitrogen inputs appears to be limited by the availability of another essential nutrient, phosphorus, which is present at relatively low concentrations in rainwater. This is the first study to directly examine the nutritional status of phytoplankton in relation to the impacts of rainwater nitrogen addition on primary production in oceanic waters off the U.S. East Coast.

\section{Introduction}

Atmospheric deposition provides an important source of macronutrients, micronutrients, and toxicants to the surface ocean (Duce et al., 2008; Guieu et al., 2014; Jickells et al., 2016; Jickells \& Moore, 2015; I.-N. Kim, Lee et al., 2014; Mahowald et al., 2010; Prospero et al., 1996). Nearshore regions are expected to receive the largest atmospheric inputs of bioactive chemical species, given their proximity to natural and anthropogenic sources of aerosols and gases that may impact biological production in adjacent nutrient-poor ocean waters. One such area is the continental shelf and slope of the Mid-Atlantic Bight, off the U.S. eastern seaboard, where surface waters typically become nutrient deficient during the summer months, and there is some evidence that links atmospheric nutrient deposition to elevated phytoplankton biomass (e.g., T.-W. Kim, Najjar, \& Lee, 2014; Paerl, 1985; Paerl et al., 1999; Willey \& Cahoon, 1991). Previous studies in this region have focused on atmospheric nitrogen $(\mathrm{N})$ deposition, which is relatively high over the North Atlantic Ocean (Jickells, 2006; Paulot et al., 2015; Zamora et al., 2010), where anthropogenic emissions from surrounding continents account for as much as $80 \%$ of the air to sea $\mathrm{N}$ flux (Duce et al., 2008). 
There is also good reason to consider the atmospheric deposition of phosphorus $(\mathrm{P})$ and iron (Fe), which have been implicated as limiting $(\mathrm{Fe})$ or colimiting $(\mathrm{Fe}, \mathrm{P})$ to primary production in the North Atlantic Ocean (Browning, Achterberg, Rapp, et al., 2017; Browning, Achterberg, Yong, et al., 2017; Moore et al., 2008, 2013; Paerl et al., 1999; Wu et al., 2000). The molar ratio of inorganic $\mathrm{N}$ to soluble reactive $\mathrm{P}$ in aerosols and rainwater is generally higher than the Redfield ratio (Baker et al., 2003, 2010; Zamora et al., 2013), such that atmospheric deposition to nutrient-depleted waters may potentially result in a secondary limitation of phytoplankton growth due to P deficiency (Fanning, 1989; Moore et al., 2008, 2013; Wu et al., 2000). In addition, despite the expectation of relatively high dissolved Fe concentrations ( $>0.3 \mathrm{nM})$ in the Mid-Atlantic Bight during summer (Wu \& Luther, 1994), phytoplankton blooms can draw dissolved Fe down to low concentrations $(\sim 0.1 \mathrm{nM})$, even in coastal settings and in regions where annual dust deposition is high (e.g., Birchill et al., 2017, Hutchins et al., 1998, Sedwick et al., 2005). Indeed, based on results of shipboard experiments, Paerl et al. (1999) have suggested that Fe availability might regulate phytoplankton growth in oligotrophic waters offshore of North Carolina, although corresponding data on seawater Fe concentrations are lacking.

A recent analysis of satellite data by T.-W. Kim, Najjar, and Lee (2014) has demonstrated an association between precipitation events and chlorophyll biomass accumulation in seasonally oligotrophic coastal waters off the southeastern United States, which they posit reflects stimulation of primary production by wet deposition of biologically available N. The project Deposition of Atmospheric Nitrogen to Coastal Ecosystems set out to test this hypothesis, using a combination of field observations and numerical model simulations. Here we report results from the field component of this project, during which water column measurements and shipboard experiments were used to establish the nutritional status of phytoplankton in seasonally oligotrophic waters of the Mid-Atlantic Bight, and to assess the potential for atmospheric deposition of $\mathrm{N}, \mathrm{P}$, and Fe to stimulate primary production in this ocean region during summer.

\section{Methods}

\subsection{Water Column Sampling and Analyses}

Water column hydrographic data and samples were collected in the Mid-Atlantic Bight aboard the RV Hugh R. Sharp, 1-14 August 2014. During this cruise we focused our observations and sampling in two oligotrophic, anticyclonic eddies that were identified using satellite sea level altimetry data. These eddies were located over the continental slope to the north ("eddy 1") and south ("eddy 2") of the Gulf Stream (Figure 1). Water column profiles of temperature, salinity, chlorophyll fluorescence, and samples for analysis of dissolved nitrate and nitrite, dissolved phosphate, and dissolved Fe were collected using a trace metal clean conductivity-temperature-depth sensor (SBE 19 plus, SeaBird Electronics) mounted on a custom-built trace metal clean carousel (SeaBird Electronics) fitted with custom-modified 5-L Teflon-lined external-closure Niskin-X samplers (General Oceanics), deployed on a Kevlar line.

Inside a trace metal clean container laboratory, water column samples were immediately filtered through precleaned $0.2 \mu \mathrm{m}$ pore AcroPak Supor filter capsules (Pall) into $60 \mathrm{~mL}$ polypropylene tubes (Falcon) for shipboard macronutrient analyses, and acid-cleaned $125 \mathrm{~mL}$ low-density polyethylene bottles (Nalgene) for shore-based dissolved iron determinations. Dissolved nitrate and nitrite and dissolved phosphate were determined at sea using an Astoria Pacific nutrient autoanalyzer using standard colorimetric methods with estimated detection limits of $0.14 \mu \mathrm{M}$ and $0.03 \mu \mathrm{M}$, respectively (Parsons et al., 1984; Price \& Harrison, 1987). In surface waters, nitrate and nitrite were determined using the same autoanalyzer equipped with a liquid waveguide capillary cell (World Precision Instruments) (Zhang, 2000) to achieve a detection limit of $0.02 \mu \mathrm{M}$. Dissolved ammonium was determined at sea using the manual orthophthaldialdehyde method (Holmes et al., 1999) with an estimated detection limit of $10 \mathrm{nM}$. Dissolved Fe was determined postcruise using flow injection analysis (Sedwick et al., 2015), with an estimated detection limit of $0.04 \mathrm{nM}$.

\subsection{Shipboard Bioassay Experiments}

For the three shipboard bioassay experiments, near-surface ( 4 $\mathrm{m}$ depth) seawater and resident plankton were collected using a trace metal clean underway "towfish" system (Sedwick et al., 2011), which was used to fill two $60 \mathrm{~L}$ polyethylene carboys in parallel inside the shipboard trace metal clean container laboratory, after passing through precleaned $180 \mu \mathrm{m}$ nylon screen to exclude larger organisms. From these carboys, $2 \mathrm{~L}$ aliquots of seawater were dispensed into fifty-six $2.4 \mathrm{~L}$ Nalgene polycarbonate bottles, which were 

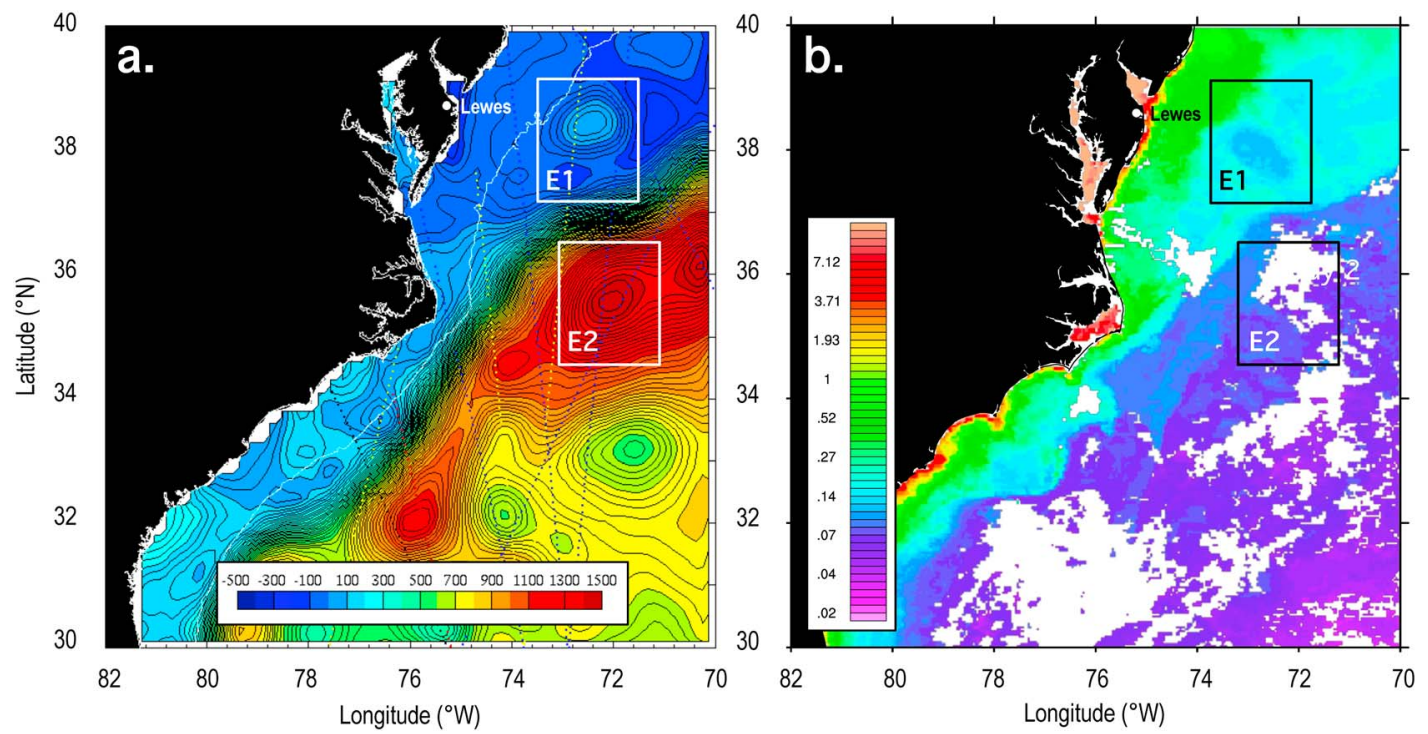

Figure 1. Location of eddies 1 (E1) and 2 (E2) sampled during this study off the U.S. eastern seaboard, with Lewes, Delaware, shown, overlain on (a) sea level anomaly on 6 August 2014, with color scale in millimeters (analysis provided by Dennis McGillicuddy and Valery Kosnyrev, using altimeter products produced and distributed by AVISO (www.aviso.oceanobs.com/) as part of the Ssalto ground processing segment), and (b) surface cholorophyll $a$, for 5-12 August 2014, with color scale in $\mathrm{mg} \mathrm{m}^{-3}$, estimated from a composite of satellite data from Terra Moderate Resolution Imaging Spectroradiometer, Aqua Moderate Resolution Imaging Spectroradiometer, and the Visible and Infrared Scanner (analysis provided by Andrew Ross).

immediately amended with macronutrients and/or iron or rainwater (described below), capped and sealed with polyvinyl chloride tape, and placed in deckboard acrylic incubator tanks. These tanks were shaded to $\sim 55 \%$ of incident irradiance with neutral density screening to simulate in situ irradiance in the upper mixed layer and were supplied with circulating surface seawater to maintain them near ambient sea temperature. Subsamples for analyses of initial concentrations dissolved ammonium and Fe were taken directly from the towfish line outlet after filtration with a 0.8/0.2 $\mu \mathrm{m}$ AcroPak Supor filter capsule (Pall), before and after filling the $60 \mathrm{~L}$ carboys, whereas subsamples for analysis of initial nitrate, nitrite, phosphate (filtered through $0.8 \mu \mathrm{m}$ pore size AcroDisc Supor syringe filters; Pall), and chlorophyll $a$ (filtered on to combusted $0.7 \mu \mathrm{m}$ pore size GF/F filters; Whatman) were taken from the seawater remaining in the $60 \mathrm{~L}$ carboys.

The $2 \mathrm{~L}$ seawater aliquots were amended by adding either (1) nitrate $(+2.4 \mu \mathrm{M}),(2)$ Fe $(+1.4 \mathrm{nM}),(3)$ nitrate and Fe (+2.4 $\mu \mathrm{M}$ and $+1.4 \mathrm{nM}$, respectively), (4) nitrate and Fe and $\mathrm{P}(+2.4 \mu \mathrm{M},+1.4 \mathrm{nM}$, and $+0.24 \mu \mathrm{M}$, respectively), or (5) $100 \mathrm{~mL}$ of a filtered rainwater composite corresponding to additions of $+0.73 \mu \mathrm{m}$ nitrate, $+2.9 \mathrm{nM} \mathrm{Fe},+0.007 \mu \mathrm{M} \mathrm{P}$, and $+1.7 \mu \mathrm{M}$ ammonium (these nutrient and/or iron concentrations were added to the ambient seawater; ambient seawater conditions are described in section 3). Bottles of unamended seawater served as control incubations. In addition, $100 \mathrm{~mL}$ of ultrapure deionized water (18.2 $\mathrm{M} \Omega \mathrm{cm}$ resistivity, Barnstead Nanopure) was added to treatments (1)-(4) and the control treatments, to achieve the same salinity as the rainwater-amended bottles. Nitrate and $\mathrm{P}$ were added as $20 \mathrm{mM}$ sodium nitrate and $2 \mathrm{mM}$ potassium dihydrogen phosphate solutions, respectively, which had been purified to remove iron and other trace metals as described by Sedwick et al. (2002); Fe was added as a $17.9 \mu \mathrm{M}$ solution of ferric nitrate in $0.1 \%$ hydrochloric acid. The rainwater added was a composite of combined $0.2 \mu \mathrm{m}$ filtered samples collected from several rain events at Old Dominion University, Norfolk, Virginia, USA, and was stored frozen prior to the cruise, when it was thawed and stored in a shipboard refrigerator. For the rainwater treatments, the rainwater to seawater mixing ratio $(100 \mathrm{~mL}$ to $2 \mathrm{~L})$ is equivalent to $250 \mathrm{~mm}(\sim 10 \mathrm{in}$.) of precipitation over a $5 \mathrm{~m}$ surface mixed layer; that is, an intense rain event. All sample containers were precleaned and experimental manipulations were performed following rigorous trace metal clean protocols (e.g., Sedwick et al., 1999, 2002).

Over the course of each incubation experiment, triplicate bottles for each treatment were sacrificed (i.e., completely subsampled) at three time points. These time points were chosen based on observed accumulation of chlorophyll $a$ in additional "monitoring" bottles that were amended with nitrate, iron, and 
phosphate and incubated alongside the other bottles. The time points were typically separated by about 1 day, or less for the first sampling point. From each sacrificed incubation bottle, subsamples were filtered with $0.8 \mu \mathrm{m}$ pore size AcroDisc Supor syringe filters (Pall) for measurement of dissolved macronutrients, or with combusted $0.7 \mu \mathrm{m}$ pore size GF/F filters (Whatman) used for fluorimetric determination of chlorophyll $a$ (Chl a) (Welschmeyer, 1994). Primary productivity was also estimated at each sampling time point by incubating $1 \mathrm{~L}$ subsamples amended with $200 \mu \mathrm{M}$ of carbon-13 $\left({ }^{13} \mathrm{C}\right)$ labeled bicarbonate (final enrichment 9.2\%) in polycarbonate bottles in the screened deck incubators from sunrise ( 6:30 a.m.) to sunset ( 9:00 p.m.), then filtering the contents of the bottles through precombusted GF/F filters, which were frozen for transport to the laboratory. In the laboratory, these filters were dried and pelletized in tin discs, and the ratio of ${ }^{13} \mathrm{C}$ to carbon-12 was measured using a Europa isotope ratio mass spectrometer. Primary productivity was calculated using a mixing model (Montoya et al., 1996) and the equations presented by Mulholland and Bernhardt (2005). Because of the limited volumes available in the incubation bottles, rates were not corrected for dark ${ }^{13} \mathrm{C}$ uptake.

In interpreting the results of the bioassay experiments, we infer (1) net algal community growth rates in the incubation bottles from accumulation of algal biomass, as indicated by increases in chlorophyll $a$ and decreases dissolved inorganic nitrogen concentrations; and (2) net primary production from the ${ }^{13} \mathrm{C}$-based productivity measurements, which likely provide values that represent somewhere between net and gross primary production rates. These experiments are principally intended to be diagnostic: where biomass accumulation, nutrient drawdown, and primary production are significantly enhanced in bottles treated with nutrients and/or iron, relative to control treatments, we infer that algal community growth rates were limited by deficiencies in those nutrients and/or iron. However, due to potential "bottle effects" (e.g., Venrick et al., 1977), the predictive capability of such experiments is unlikely to be robust.

\section{Results and Discussion}

The two anticyclonic eddies sampled (Figure 1) were characterized by shallow surface mixed layers $(<20 \mathrm{~m})$, with low phytoplankton biomass $\left(<0.1 \mu \mathrm{g} \mathrm{L}^{-1} \mathrm{Chl} a\right)$, low concentrations $(<0.2 \mu \mathrm{M})$ of dissolved inorganic $\mathrm{N}$ (DIN = nitrate + nitrite + ammonium) and dissolved phosphate, and moderate concentrations ( 0.2-1 nM) of dissolved $\mathrm{Fe}$ in the upper water column, which are comparable to values observed in the oligotrophic Sargasso Sea during summer (e.g., Sedwick et al., 2005). Representative vertical profiles of temperature, salinity, in situ chlorophyll fluorescence, and the concentrations of dissolved nitrate + nitrite and dissolved Fe for each eddy are shown in Figure 2. Eddy 1 (located north of the Gulf Stream) exhibited a slightly shallower, cooler, and saltier surface mixed layer, slightly higher concentrations of dissolved nitrate + nitrite, and lower concentrations of dissolved Fe, relative to eddy 2 (located south of the Gulf Stream). Two shipboard bioassay experiments (experiments 1 and 2) used seawater collected from eddy 1 , and one experiment (experiment 3) used seawater collected from eddy 2.

The three bioassay experiments yielded generally consistent results, which are well illustrated by the statistically significant differences in the accumulation of $\mathrm{Chl} a$ between the experimental treatments (Figure 3), where experimental uncertainties are estimated as \pm 1 standard deviation on the mean of values measured for each triplicate incubation treatment. For each experiment, the order of increasing $\mathrm{Chl} a$ accumulation, relative to the unamended control treatments, was $+\mathrm{Fe}$ (little or no difference from control); + nitrate and + nitrate + Fe (both treatments elicited similarly modest yet significant increases in Chl $a$ ); +rainwater (substantial increases in $\mathrm{Chl} a$ ); and + nitrate $+\mathrm{Fe}+\mathrm{P}$ (largest increases in $\mathrm{Chl} a$ ). The ${ }^{13} \mathrm{C}$-based primary production estimates convey a similar picture, with the highest production rates in the nitrate $+\mathrm{Fe}+\mathrm{P}$ treatments, and significantly elevated rates in the + nitrate, + nitrate + $\mathrm{Fe}$, and + rainwater treatments, relative to the control incubations (Figure 4). Assimilation numbers calculated for the final samples (3.2-13.9; Table S1 in the supporting information) fall within the typical range for marine phytoplankton (e.g., Harrison \& Platt, 1980; Picart et al., 2014) but show no clear trend in the three experiments.

The + nitrate,+ nitrate $+\mathrm{Fe}$, and + nitrate $+\mathrm{Fe}+\mathrm{P}$ treatments all exhibited a significant drawdown in nitrate + nitrite concentrations during the course of the experiments (Figure 5), presumedly due to assimilation by phytoplankton, and consistent with observed accumulations of $\mathrm{Chl} a$ and increases in primary production relative to the control treatments. However, the incubation bottles amended with rainwater (which initially contained $0.81-0.96 \mu \mathrm{M}$ nitrate + nitrite and $1.72 \mu \mathrm{M}$ ammonium; Table S1) showed no 

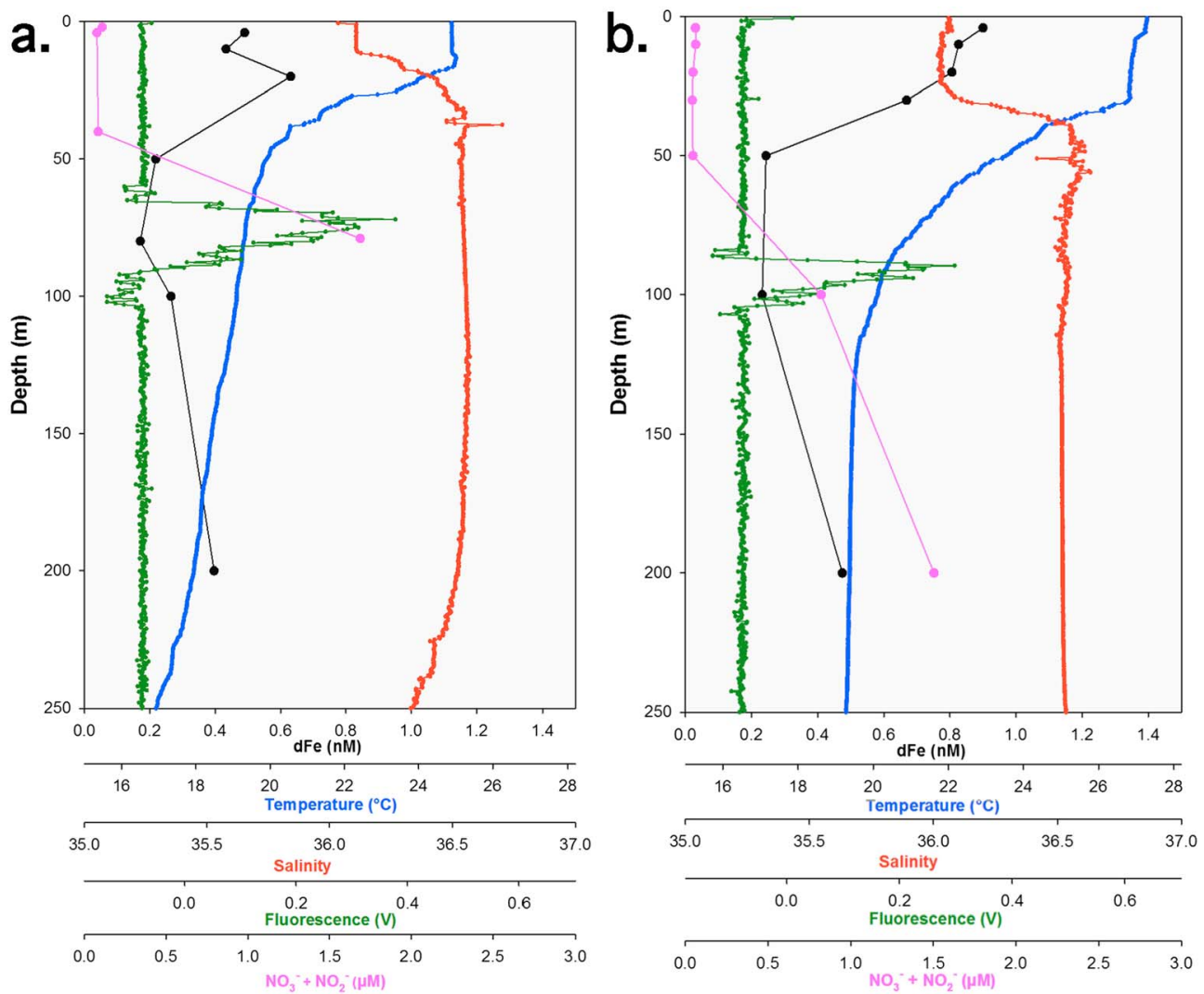

Figure 2. Upper water column profiles of dissolved iron (dFe) concentration, temperature, salinity, in situ chlorophyll fluorescence, and dissolved nitrate + nitrite $\left(\mathrm{NO}_{3}{ }^{-}+\mathrm{NO}_{2}{ }^{-}\right)$concentrations from (a) eddy 1 , immediately before sampling for experiment 1 , and (b) eddy 2 , immediately before sampling for experiment 3 .

significant drawdown in nitrate + nitrite, despite substantial accumulations of Chl $a$ (Figure 5). This apparent incongruity is reconciled by the measured drawdown of $0.37-1.23 \mu \mathrm{M}$ ammonium in the rainwater-amended bottles (Table S1), noting that no ammonium was added in the other experimental treatments. This result is not surprising, given that uptake of ammonium is energetically favorable for phytoplankton, relative to
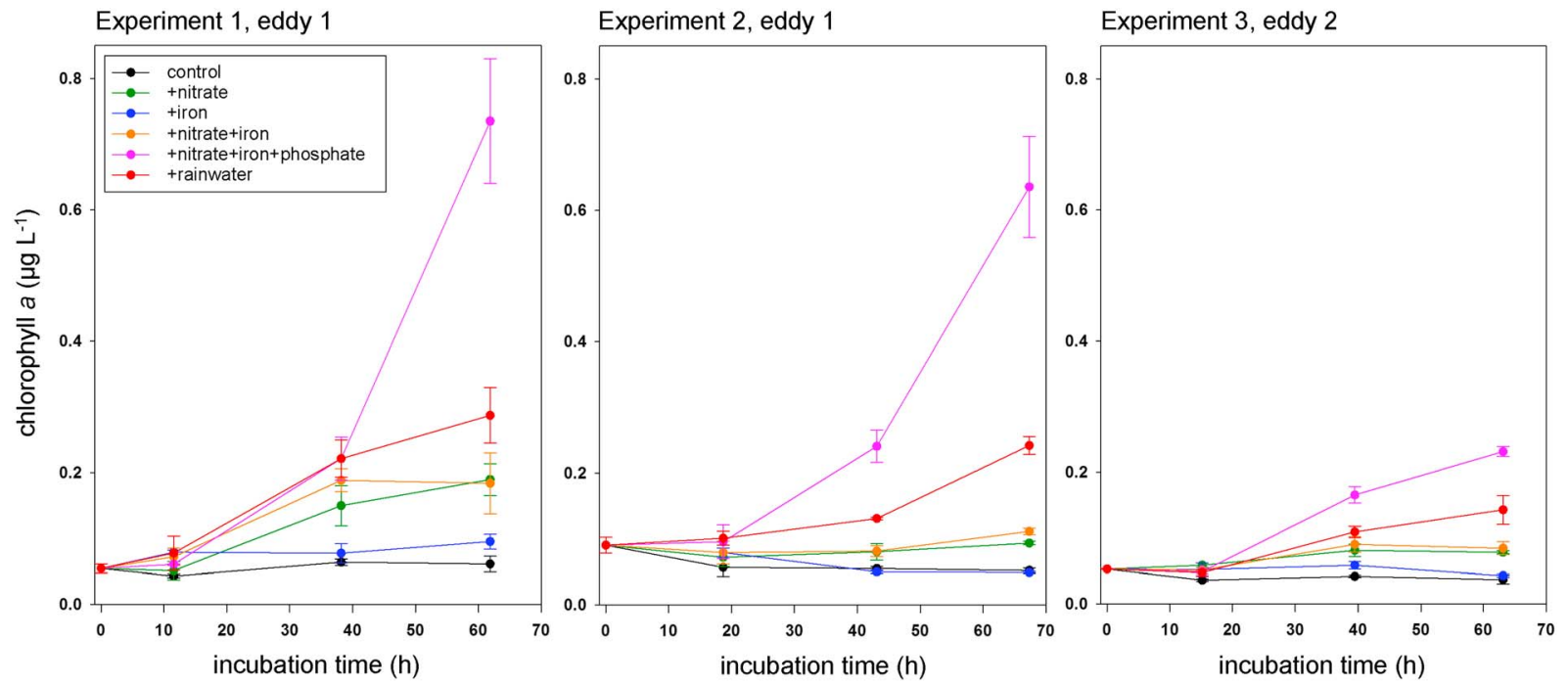

Figure 3. Particulate cholorophyll $a$ concentrations in incubation bottles for each treatment as a function of time for the three bioassay experiments. Each data point represents the mean value for triplicate bottles, with error bars representing \pm 1 standard deviation on the mean. 

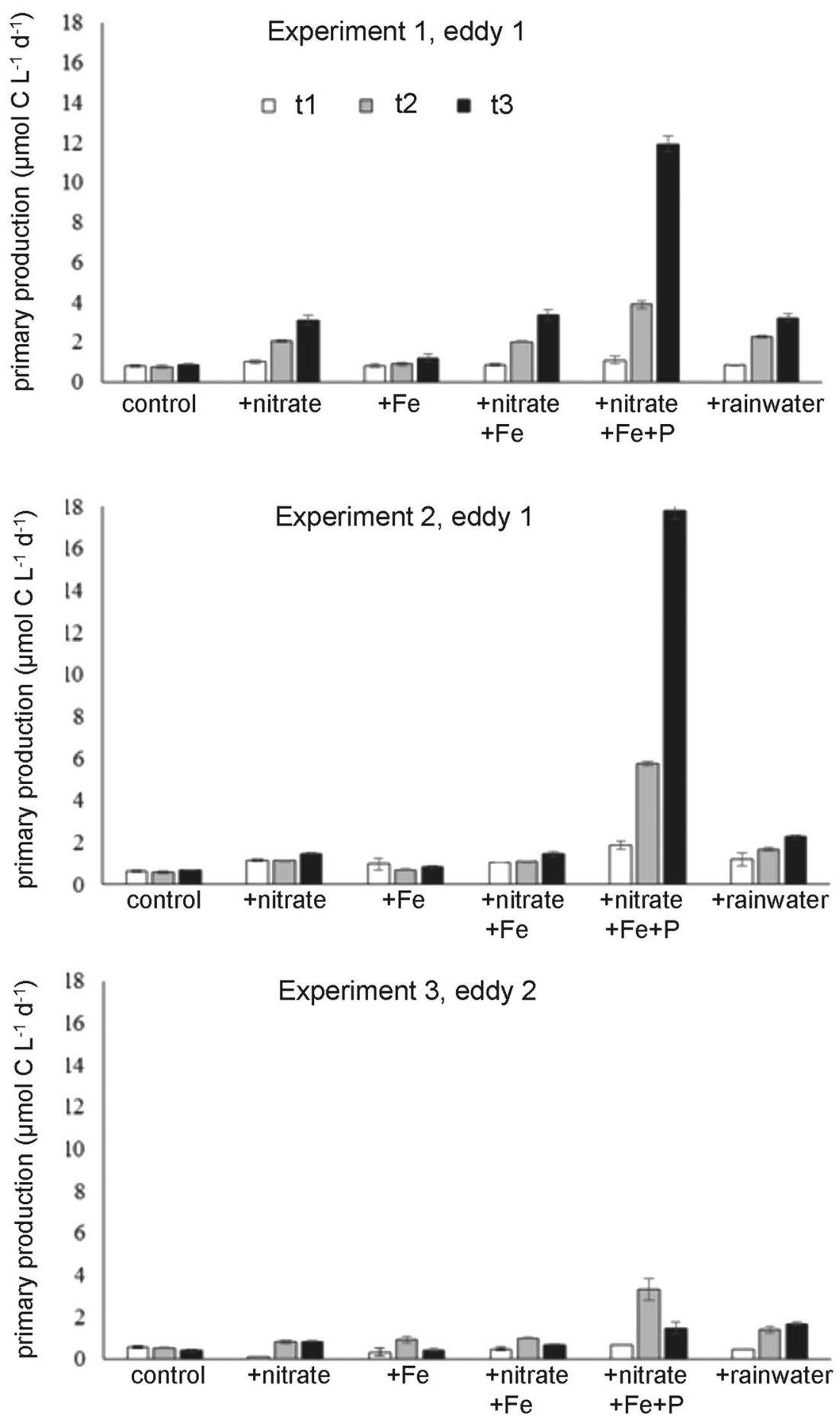

Figure 4. Primary production estimated from ${ }^{13} \mathrm{C}$ uptake in incubated subsamples taken from the different experimental treatments in the three bioassay experiments; $\mathrm{t} 1, \mathrm{t} 2$, and $\mathrm{t} 3$ refer to the first, second, and third sampling time points, respectively.

nitrate uptake (Mulholland \& Lomas, 2008). Thus, uptake of ammonium likely supported most of the biomass accumulation in the bottles amended with rainwater, with 0.18-0.19 $\mu \mathrm{g} \mathrm{Chl} a$ produced per $\mu \mathrm{mol}$ DIN consumed in the three experiments (Table S1). The control and + Fe treatments, in which Chl $a$ did not significantly accumulate, generally showed slight increases in nitrite + nitrate concentrations $(0.05-0.37 \mu \mathrm{M}$, Figure 5 and Table S1) during the incubations, perhaps reflecting cellular release or remineralization and nitrification (e.g., Clark et al., 2008). 

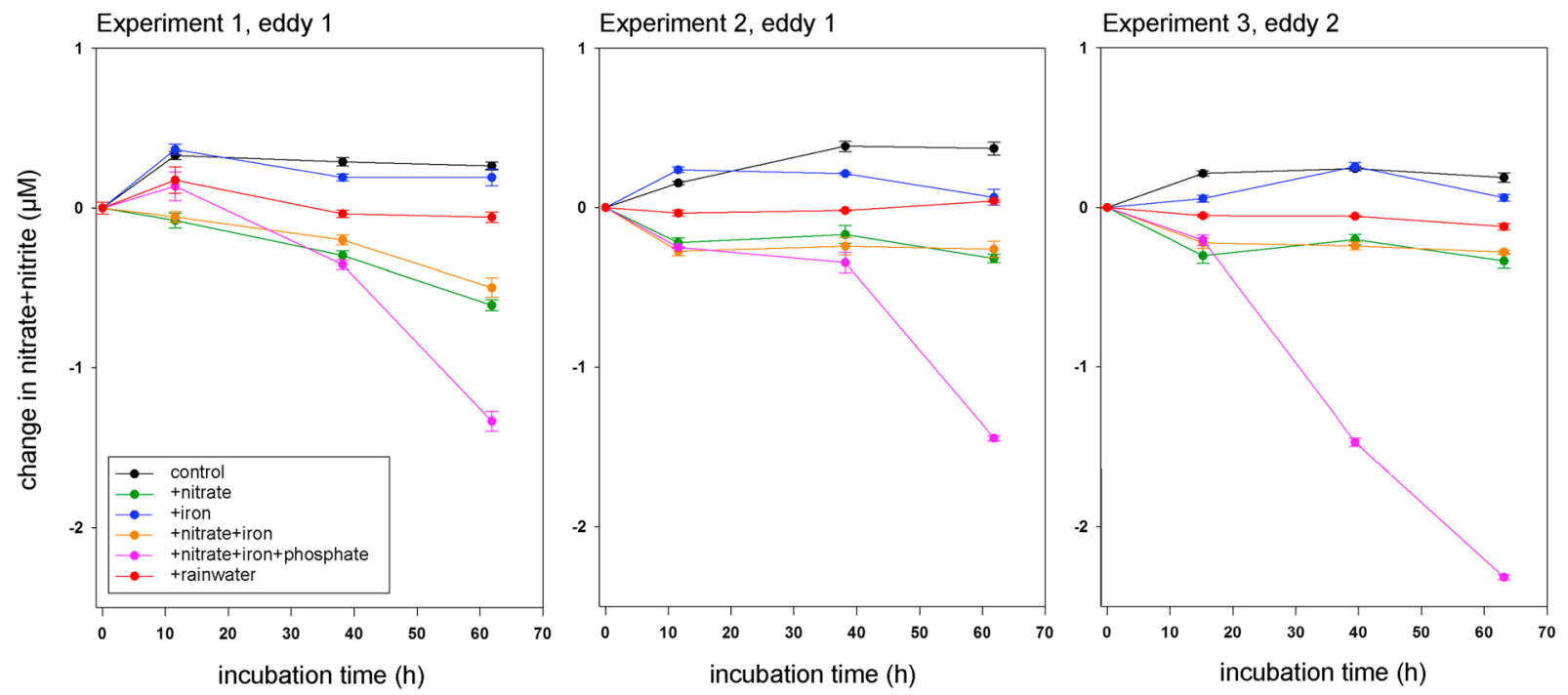

Figure 5. Net change in dissolved nitrate + nitrite concentration in incubation bottles, relative to initial amended concentration, for each treatment as a function of time for the three bioassay experiments. Each data point represents the mean value for triplicate bottles, with error bars representing \pm 1 standard deviation on the mean.

In interpreting these bioassay results, we attribute differences in the accumulation of $\mathrm{Chl} a$ (Figure 3) and drawdown of DIN (Figure 5 and Table S1), relative to control treatments, to differences in the net growth rate of phytoplankton between the different experimental treatments (Sedwick et al., 2002). This interpretation is wholly consistent with the primary production rates estimated from ${ }^{13} \mathrm{C}$ uptake in subsamples incubated from the experimental treatments (Figure 4). For all three experiments, there was no evidence for enhanced growth after addition of $\mathrm{Fe}$ alone, whereas addition of nitrate, either with or without $\mathrm{Fe}$, elicited increased $\mathrm{Chl}$ $a$ and nitrate + nitrite drawdown: this indicates that $\mathrm{N}$ deficiency was the proximate limitation on phytoplankton community growth in the surface waters of eddies 1 and 2. Moreover, the yet greater accumulation of $\mathrm{Chl}$ $a$ and drawdown of DIN in the + rainwater and + nitrate + Fe + P treatments, both of which were amended with inorganic $\mathrm{P}$ as well as inorganic $\mathrm{N}$, implies that $\mathrm{P}$ deficiency exerts a secondary limitation on phytoplankton growth in these waters, as has been suggested for the oligotrophic waters of the subtropical North Atlantic (Moore et al., 2008, 2013).

Here we note that although similar concentrations of inorganic $\mathrm{N}$ (as nitrate or ammonium) were added in the + rainwater and + nitrate $+\mathrm{Fe}+\mathrm{P}$ treatments (around $2.4 \mu \mathrm{M}$ ), the + nitrate $+\mathrm{Fe}+\mathrm{P}$ treatment included $\sim 0.24 \mu \mathrm{M}$ more phosphate and elicited a significantly greater growth response (Figures 3 and 4 and Table S1). This response is readily interpreted by considering the stoichiometric ratios of the added inorganic $N$ and $P$ : the rainwater addition had a molar inorganic N:P ratio of $\sim 350$ (much greater than Redfield), whereas the + nitrate $+\mathrm{Fe}+\mathrm{P}$ treatment had a molar N:P ratio of 10 (slightly less than Redfield). These observations suggest that phytoplankton lacked sufficient $P$ to utilize all of the inorganic $\mathrm{N}$ that was added to the rainwater-amended bottles. This result has important implications for the potential of rain events to stimulate primary production in our study region during summer, where atmospheric deposition typically has an inorganic N:P ratio much greater than the Redfield ratio (Baker et al., 2003, 2010; Zamora et al., 2013; C. Sookhdeo, unpublished data, 2017). The relative inputs of N and $\mathrm{P}$ might then be expected to restrict the capacity for wet deposition to stimulate primary production, because the biological utilization of atmospherically supplied $N$ will be limited by the combined inventory of ambient and atmospherically supplied inorganic $\mathrm{P}$ in surface seawater. However, this secondary $\mathrm{P}$ limitation may be mitigated if phytoplankton are able to utilize the pool of dissolved organic phosphorus, which is typically present at concentrations 5-10 times greater than phosphate (e.g., see Mahaffey et al., 2014). Finally, contrary to the findings of Paerl et al. (1999), our field measurements and experimental results provide no evidence that availability of dissolved Fe limits phytoplankton growth in this ocean region during summer, implying that eolian and neritic sources supply sufficient Fe to support primary production. 
Acknowledgments

We thank the captain and crew of RV Hugh R. Sharp, as well as Christian Kernisan and the other DANCE cruise participants for their assistance with this work. The thoughtful comments and suggestions provided by two anonymous reviewers improved the paper. This research was supported by U.S. National Science Foundation awards OCE-1260454 to M. R. M. and P. N. S. and OCE-1260574 to R. G. N. Data discussed in this paper are provided in the supporting information, with full data archived at and available from the Biological and Chemical Oceanography Data Management Office (www.bcodmo.org) under project 726328.

\section{References}

Baker, A. R., Kelly, S. D., Biswas, K. F., Witt, M., \& Jickells, T. D. (2003). Atmospheric deposition of nutrients to the Atlantic Ocean. Geophysical Research Letters, 30(24), 2296. https://doi.org/10.1029/2003GL018518

Baker, A. R., Lesworth, T., Adams, C., Jickells, T. D., \& Ganzeveld, L. (2010). Estimation of atmospheric nutrient inputs to the Atlantic Ocean from $50^{\circ} \mathrm{N}$ to $50^{\circ} \mathrm{S}$ based on large-scale field sampling: Fixed nitrogen and dry deposition of phosphorus. Global Biogeochemical Cycles, 24 , GB3006. https://doi.org/10.1029/2009GB003634

Birchill, A. J., Milne, A., Woodward, E. M. S., Harris, C., Annett, A., Rusiecka, D., et al. (2017). Seasonal iron depletion in temperate shelf seas. Geophysical Research Letters, 44, 8987-8996. https://doi.org/10.1002/2017GL073881

Browning, T. J., Achterberg, E. P., Rapp, I., Engel, A., Bertrand, E. M., Tagliabue, A., \& Moore, C. M. (2017). Nutrient co-limitation at the boundary of an oceanic gyre. Nature, 551(7679), 242-246. https://doi.org/10.1038/nature24063

Browning, T. J., Achterberg, E. P., Yong, J. C., Rapp, I., Utermann, C., Engel, A., \& Moore, C. M. (2017). Iron limitation of microbial phosphorus acquisition in the tropical North Atlantic. Nature Communications, 8. https://doi.org/10.1038/ncomms 15465

Clark, D. R., Rees, A. P., \& Joint, I. (2008). Ammonium regeneration and nitrification rates in the oligotrophic Atlantic Ocean: Implications for new production estimates. Limnology and Oceanography, 53(1), 52-62. https://doi.org/10.4319/lo.2008.53.1.0052

Duce, R. A., LaRoche, J., Altieri, K., Arrigo, K. R., Baker, A. R., Capone, D. G., et al. (2008). Impacts of atmospheric anthropogenic nitrogen on the open ocean. Science, 320(5878), 893-897. https://doi.org/10.1126/science.1150369

Fanning, K. A. (1989). Influence of atmospheric pollution on nutrient limitation in the ocean. Nature, 339(6224), 460-463. https://doi.org/ 10.1038/339460a0

Guieu, C., Aumont, O., Paytan, A., Bopp, L., Law, C. S., Mahowald, N., et al. (2014). The significance of the episodic nature of atmospheric deposition to low nutrient low chlorophyll regions. Global Biogeochemical Cycles, 28, 1179-1198. https://doi.org/10.1002/ 2014GB004852

Harrison, W. G., \& Platt, T. (1980). Variations in assimilation number of coastal marine phyto-phytoplankton: Effects of environmental covariates. Journal of Plankton Research, 2(4), 249-260. https://doi.org/10.1093/plankt/2.4.249

Holmes, R. M., Aminot, A., Kérouel, R., Hooker, B. A., \& Peterson, B. J. (1999). A simple and precise method for measuring ammonium in marine and freshwater ecosystems. Canadian Journal of Fisheries and Aquatic Sciences, 56(10), 1801-1808. https://doi.org/10.1139/f99-128

Hutchins, D. A., DiTullio, G. R., Zhang, Y., \& Bruland, K. W. (1998). An iron limitation mosaic in the California upwelling regime. Limnology and Oceanography, 43(6), 1037-1054. https://doi.org/10.4319/lo.1998.43.6.1037

Jickells, T. (2006). The role of air-sea exchange in the marine nitrogen cycle. Biogeosciences Discussions, 3(1), 183-210. https://doi.org/ $10.5194 /$ bgd-3-183-2006

Jickells, T., \& Moore, C. M. (2015). The importance of atmospheric deposition for ocean productivity. Annual Review of Ecology, Evolution, and Systematics, 46(1), 481-501. https://doi.org/10.1146/annurev-ecolsys-112414-054118

Jickells, T. D., Baker, A. R., \& Chance, R. (2016). Atmospheric transport of trace elements and nutrients to the oceans. Philosophical Transactions of the Royal Society A, 374, 20150286. https://doi.org/10.1098/rsta.2015.0286

Kim, T.-W., Najjar, R. G., \& Lee, K. (2014). Influence of precipitation events on phytoplankton biomass in coastal waters of the eastern United States. Global Biogeochemical Cycles, 28, 1-13. https://doi.org/10.1002/2013GB004712

Kim, I.-N., Lee, K., Gruber, N., Karl, D. M., Bullister, J. L., Yang, S., \& Kim, T.-W. (2014). Increasing anthropogenic nitrogen in the North Pacific Ocean. Science, 346(6213), 1102-1106. https://doi.org/10.1126/science.1258396

Mahaffey, C., Reynolds, S., Davis, C. E., \& Lohan, M. C. (2014). Alkaline phosphatase activity in the subtropical ocean: Insights from nutrient, dust and trace metal addition experiments. Frontiers in Marine Science, 1, 73.

Mahowald, N. M., Kloster, S., Engelstaedter, S., Moore, J. K., Mukhopadhyay, S., McConnell, J. R., et al. (2010). Observed 20th century desert dust variability: Impact on climate and biogeochemistry. Atmospheric Chemistry and Physics, 10(22), 10875-10893. https://doi.org/ 10.5194/acp-10-10875-2010

Montoya, J. P., Voss, M., Kahler, P., \& Capone, D. G. (1996). A simple, high-precision, high-sensitivity tracer assay for $\mathrm{N}_{2}$ fixation. Applied and Environmental Microbiology, 62(3), 986-993.

Moore, C. M., Mills, M. M., Langlois, R., Milne, A., Achterberg, E. P., La Roche, J., \& Geider, R. J. (2008). Relative influence of nitrogen and phosphorous availability on phytoplankton physiology and productivity in the oligotrophic sub-tropical North Atlantic Ocean. Limnology and Oceanography, 53(1), 291-305. https://doi.org/10.4319/lo.2008.53.1.0291

Moore, C. M., Mills, M. M., Arrigo, K. R., Berman-Frank, I., Bopp, L., Boyd, P. W., et al. (2013). Processes and patterns of oceanic nutrient limitation. Nature Geoscience, 6(9), 701-710. https://doi.org/10.1038/ngeo1765

Mulholland, M. R., \& Bernhardt, P. W. (2005). The effect of growth rate, phosphorus concentration, and temperature on $\mathrm{N}_{2}$ fixation, carbon fixation, and nitrogen release in continuous cultures of Trichodesmium IMS101. Limnology and Oceanography, 50(3), 839-849. https://doi. org/10.4319/lo.2005.50.3.0839

Mulholland, M. R., \& Lomas, M. W. (2008). Nitrogen uptake and assimilation. In D. G. Capone, D. A. Bronk, M. R. Mulholland, \& E. J. Carpenter (Eds.), Nitrogen in the marine environment (Chap. 7, pp. 303-384). Burlington, MA: Academic Press. https://doi.org/10.1016/B978-0-12372522-6.00007-4

Paerl, H. W. (1985). Enhancement of marine primary productivity by nitrogen enriched rain. Nature, 315(6022), 747-749. https://doi.org/ $10.1038 / 315747 a 0$

Paerl, H. W., Willey, J. D., Go, M., Peierls, B. L., Pinckney, J. L., \& Fogel, M. L. (1999). Rainfall stimulation of primary production in western Atlantic Ocean waters: Roles of different nitrogen sources and colimiting nutrients. Marine Ecology Progress Series, 176, 205-214. https://doi.org/ 10.3354/meps176205

Parsons, T. R., Maita, Y., \& Lalli, C. M. (1984). A manual of chemical and biological methods of seawater analysis. Oxford: Pergamon Press.

Paulot, F., Jacob, D. J., Johnson, M. T., Bell, T. G., Baker, A. R., Keene, W. C., et al. (2015). Global oceanic emission of ammonia: Constraints from seawater and atmospheric observations. Global Biogeochemical Cycles, 29, 1165-1178. https://doi.org/10.1002/2015GB005106

Picart, S. S., Sathyendranath, S., Dowell, M., Moore, T., \& Platt, T. (2014). Remote sensing of assimilation number for marine phytoplankton. Remote Sensing of Environment, 146, 87-96. https://doi.org/10.1016/j.rse.2013.10.032

Price, N. M., \& Harrison, P. J. (1987). Comparison of methods for the analysis of dissolved urea in seawater. Marine Biology, 94(2), 307-317. https://doi.org/10.1007/BF00392945

Prospero, J. M., Barrett, K., Church, T., Dentener, F., Duce, R. A., Galloway, J. N., et al. (1996). Atmospheric deposition of nutrients to the North Atlantic Basin. Biogeochemistry, 35(1), 27-73. https://doi.org/10.1007/BF02179824

Sedwick, P. N., DiTullio, G. R., Hutchins, D. A., Boyd, P. W., Griffiths, F. B., Crossley, A. C., et al. (1999). Limitation of algal growth by iron deficiency in the Australian Subantarctic region. Geophysical Research Letters, 26(18), 2865-2868. https://doi.org/10.1029/1998GL002284 
Sedwick, P. N., Blain, S., Quéguiner, B., Griffiths, F. B., Fiala, M., Bucciarelli, E., \& Denis, M. (2002). Resource limitation of phytoplankton growth in the Crozet Basin, Subantarctic Southern Ocean. Deep Sea Research Part II: Topical Studies in Oceanography, 49(16), 3327-3349. https:// doi.org/10.1016/S0967-0645(02)00086-3

Sedwick, P. N., Church, T. M., Bowie, A. R., Marsay, C. M., Ussher, S. J., Achilles, K. M., et al. (2005). Iron in the Sargasso Sea (Bermuda Atlantic Time-series Study region) during summer: Eolian imprint, spatiotemporal variability, and ecological implications. Global Biogeochemical Cycles, 19, GB4006. https://doi.org/10.1029/2004GB002445

Sedwick, P. N., Marsay, C. M., Sohst, B. M., Aguilar-Islas, A. M., Lohan, M. C., Long, M. C., et al. (2011). Early-season depletion of dissolved iron in the Ross Sea polynya: Implications for iron dynamics on the Antarctic continental shelf. Journal of Geophysical Research, 116, C12019. https://doi.org/10.1029/2010JC006553

Sedwick, P. N., Sohst, B. M., Ussher, S. J., \& Bowie, A. R. (2015). A zonal picture of the water column distribution of dissolved iron(II) during the US GEOTRACES North Atlantic transect cruise (GEOTRACES GA03). Deep Sea Research Part II: Topical Studies in Oceanography, 116, 166-175. https://doi.org/10.1016/j.dsr2.2014.11.004

Venrick, E. L., Beers, J. R., \& Heinbokel, J. F. (1977). Possible consequences of containing microplankton for physiological rate measurements. Journal of Experimental Marine Biology and Ecology, 26(1), 55-76. https://doi.org/10.1016/0022-0981(77)90080-6

Welschmeyer, N. A. (1994). Fluorometric analysis of chlorophyll $a$ in the presence of chlorophyll $b$ and pheopigments. Limnology and Oceanography, 39(8), 1985-1992. https://doi.org/10.4319/lo.1994.39.8.1985

Willey, J. D., \& Cahoon, L. B. (1991). Enhancement of chlorophyll a production in Gulf Stream surface seawater by rainwater nitrate. Marine Chemistry, 34(1-2), 63-75. https://doi.org/10.1016/0304-4203(91)90014-N

Wu, J., \& Luther, G. W. (1994). Size-fractionated iron concentrations in the water column of the western North Atlantic Ocean. Limnology and Oceanography, 39(5), 1119-1129. https://doi.org/10.4319/lo.1994.39.5.1119

Wu, J., Sunda, W., Boyle, E. A., \& Karl, D. M. (2000). Phosphate depletion in the western North Atlantic Ocean. Science, 289(5480), 759-762. https://doi.org/10.1126/science.289.5480.759

Zamora, L. M., Landolfi, A., Oschlies, A., Hansell, D. A., Dietze, H., \& Dentener, F. (2010). Atmospheric deposition of nutrients and excess N formation in the North Atlantic. Biogeosciences, 7(2), 777-793. https://doi.org/10.5194/bg-7-777-2010

Zamora, L. M., Prospero, J. M., Hansell, D. A., \& Trapp, J. M. (2013). Atmospheric P deposition to the subtropical North Atlantic: Sources, properties, and relationship to N deposition. Journal of Geophysical Research: Atmospheres, 118, 1546-1562. https://doi.org/10.1002/ jgrd.50187

Zhang, J. Z. (2000). Shipboard automated determination of trace concentrations of nitrite and nitrate in oligotrophic water by gassegmented continuous flow analysis with a liquid waveguide capillary flow cell. Deep Sea Research Part l, 47(6), 1157-1171. https://doi. org/10.1016/S0967-0637(99)00085-0 